$1-1-2013$

\title{
Marketing and Outreach in Law Libraries: A White Paper
}

\author{
Carol A. Watson \\ Director of the Law Library University of Georgia School of Law, cwatson@uga.edu \\ Amanda Runyon \\ Director of the Law Library University of Michigan Law School \\ L. Cindy Dabney \\ Director of the Law Library Maurer School of Law - Indiana University \\ Liz McCurry Johnson \\ Director of the Law Library Wake Forest University \\ Emily Lawson \\ Director of the Law Library University of Houston
}

See next page for additional authors

b bepress $S$ SRN

\section{Repository Citation}

Carol A. Watson, Amanda Runyon, L. Cindy Dabney, Liz McCurry Johnson, Emily Lawson, Shira Megerman, Jaimie Sommer, Thomas J. Striepe, and Michele Thomas, Marketing and Outreach in Law Libraries: A White Paper, 105 Law Libr. J. 525 (2013),

Available at: https://digitalcommons.law.uga.edu/fac_artchop/1232

This Article is brought to you for free and open access by the Faculty Scholarship at Digital Commons @ University of Georgia School of Law. It has been accepted for inclusion in Scholarly Works by an authorized administrator of Digital Commons @ University of Georgia School of Law. Please share how you have benefited from this access For more information, please contact tstriepe@uga.edu. 


\section{Authors}

Carol A. Watson, Amanda Runyon, L. Cindy Dabney, Liz McCurry Johnson, Emily Lawson, Shira Megerman, Jaimie Sommer, Thomas J. Striepe, and Michele Thomas 


\title{
Marketing and Outreach in Law Libraries: A White Paper
}

\section{ALL-SIS Task Force on Library Marketing and Outreach ${ }^{*}$}

\begin{abstract}
In recent years, libraries have turned to marketing and outreach to better educate library users about services and resources while gaining an understanding of their needs. Marketing and outreach are relatively new concepts in academic law libraries, and librarians tasked with these functions have found resources and examples of this type of work to be lacking. Though focused on academic law libraries, the article identifies the challenges facing all law libraries, explains why libraries need marketing and outreach plans, and provides examples of marketing and outreach successes.
\end{abstract}

\section{Introduction}

I1 Law libraries are charged with providing services and access to information to a wide variety of users, including students, faculty, law school staff, attorneys, and the general public. Libraries constantly evolve in response to changes in teaching and learning styles, the format of information resources, methods of scholarly publishing, and the practice of law. These changes must be informed by the needs of our users; in turn, we need to inform users of the resulting improvements. Our services and resources are only valuable to our users if they are aware of them and able to use them successfully. While this white paper was originally written for academic law libraries, with services to law students in mind, most of its ideas and suggestions can be applied to any type of law library. It identifies the challenges facing law libraries, explains why libraries need marketing and outreach plans, and highlights examples of marketing and outreach successes.

\section{Why Libraries Need Marketing and Outreach}

Library marketing is outreach. It is making people aware of what we can do for them, in a language they can understand. ... We need to tell people we're here,

* The membership of the ALL-SIS Task Force on Library Marketing and Outreach included Amanda Runyon, Reference Librarian, University of Michigan Law Library (Chair); Carol A. Watson, Director of the Law Library, Alexander Campbell King Law Library, University of Georgia (Vice Chair); L. Cindy Dabney, Assistant Librarian for Outreach Services, Indiana University Law Library; Liz McCurry Johnson, Reference Librarian, Professional Center Library, Wake Forest University; Emily Lawson, Law Reference/Research Librarian, O'Quinn Law Library, University of Houston; Shira Megerman, Student Services Reference Librarian, Lawton Chiles Legal Information Center, University of Florida; Jamie Sommer, Research and Instructional Services Librarian, Pritzker Legal Research Center, Northwestern University; T.J. Striepe, Faculty Services Librarian, Alexander Campbell King Law Library, University of Georgia; and Michele Thomas, Catalog/Reference Librarian, William H. Bowen School of Law Library, University of Arkansas-Little Rock. 
explain to them how we can help, and persuade them to come in through the doors, physical or virtual. ${ }^{1}$

I2 Conversations about whether libraries will thrive or even exist in another twenty years are ubiquitous. Thanks to the Internet, users no longer see libraries as the predominant source of information. It is assumed that everything is available online or that Google searching leads to more efficient and effective research than using a library. As a result, "[p]ublic perception is at least ten years behind the reality of what we do and how we do it."2 Changing this perception will only happen through the hard work of librarians in designing and implementing high-quality marketing and outreach programs.

I3 Students' ease with locating information in their everyday life using Google or Wikipedia does not always translate to success in scholarly research, as they do not have the same familiarity with navigating scholarly information resources. Many, though, overestimate their research abilities. For example, Ian Gallacher's 2006 survey of incoming law students found that $37.1 \%$ were "very confident," and $44 \%$ were "somewhat confident" in their research ability. ${ }^{3}$ Yet reports from supervisory practicing attorneys and law firm librarians indicate that new attorneys' research skills need improvement. ${ }^{4}$ Patrick Meyer concluded that in order for the research training of law students to remain in sync with the research needs of law firms, law school instruction should include print research components and ensure that students have "a thorough understanding of the database hierarchy, search query formulation, search strategy, and overall online navigation."5 Academic law librarians' opportunities to increase students' information literacy can be limited, however, because of students' reluctance to seek out the assistance of librarians.

II4 Recent studies of college students have shown that undergraduate students are not likely to seek help from the library with research tasks. These studies are relevant to our understanding of law students as well, since most law students are of the same generation as the college students evaluated in these studies and, unless they have other graduate school experience, are not likely to have gained the familiarity with academic libraries that would otherwise shape their opinion of scholarly research.

I5 The nationwide Project Information Literacy (PIL) study surveyed college students about their information-seeking behaviors. Eight out of ten respondents reported rarely, if ever, seeking assistance from a librarian with course-related research assignments. Even when librarians provided initial training sessions on library resources and using scholarly databases during freshman orientation, students did not return to librarians to seek research help. ${ }^{6}$ Students turn to instructors

1. Ned Potter, The Library Marketing Toolkit, at xiv-xv (2012).

2. Id. at $\mathrm{xv}$.

3. Ian Gallacher, Who Are Those Guys? The Results of a Survey Studying the Information Literacy of Incoming Law Students, 44 CAL. W. L. REv. 151, 178 (2007).

4. See Patrick Meyer, Law Firm Legal Research Requirements of New Attorneys, 101 LAW LiBR. J. 297, 305-06, 2009 LAW LIBR. J. 17, III 25-27 (summarizing survey results).

5. Id. at 321, I 72 .

6. Alison Head \& Michael B. Eisenberg, Lessons learned: How College Students Seek INFORMATION IN THE DigITAL AGE 3 (2009), available at http://projectinfolit.org/pdfs/PIL_Fall2009 _YearlReport_12_2009.pdf. 
rather than librarians for assistance because instructors are seen as experts in the field and they grade the assignments. Instructors were also valued for providing comprehensive assistance throughout the entire process-from developing a topic to writing drafts to editing final papers. ${ }^{\text {? }}$

I6 A positive finding from the PIL project is that while students may not consult librarians, they do use library resources. Of the students surveyed, $84 \%$ used scholarly research databases, and 78\% used their library's online catalog. However, even though students report using library resources, they also express frustrations with their use, beginning with difficulty knowing which database or resource to select. ${ }^{8}$ Other reported difficulties include a general sense of "information overload," and an inability to locate needed information in an online search. ${ }^{9}$

I7 The Ethnographic Research in Illinois Academic Libraries (ERIAL) project investigated the research habits of university students with the goal of adjusting library services to better meet students' needs. The study found that students did not consult librarians for assistance with research projects for many reasons, including not wanting to bother library staff and being fearful of appearing ignorant or foolish for not knowing how to do research. The study also found that students did not understand what kind of help librarians can offer, and that students assumed that librarians could only help with finding known items or providing directional assistance. ${ }^{10}$

I8 One explanation for this reluctance to seek the assistance of librarians is the self-reliant nature of the Millennial generation. This generation of students is more likely to attempt to help themselves or to seek answers from the Internet before consulting an expert. ${ }^{11}$ If a student's self-teaching behavior proves inadequate, her next step is likely to be to seek help from a peer. Students turn to their peers first because they have established relationships and are working on similar assignments, allowing them to compare progress on and understanding of course materials. $^{12}$

\$9 The need for additional research training presents an opportunity for librarians. The current national spotlight on legal education is forcing law schools to address the high cost of attendance and the lack of jobs for new graduates. Law schools are under pressure to provide practical training and to lower costs, and these two goals are often at odds. Libraries can be part of the solution to this dilemma by offering their expertise and services, which in turn reinforce the library's value to the law school community. Legal research courses, taught by librarians, may be one of the most cost-effective ways for a law school to increase students' practical skills. An added benefit of building librarian-taught legal research courses into the curriculum

7. See id. at $29-30$.

8. Id. at 22 .

9. Id. at 9.

10. See College Libraries and Student Culture: What We Now Know 53 (Lynda Duke \& Andrew Asher eds., 2012) [hereinafter College Libraries].

11. See id. at 63; Debbi A. Smith, Strategic Marketing of Library Resources and Services, 18 C. \& UNDERGRADUATE LIBR. 333, 341 tbl.1 (2011).

12. See COLlege Libraries, supra note 10 , at $58-60$. 
is that students will see librarians as an integral part of their legal education and recognize them as a resource that can be consulted in the future.

\section{Changing the Conversation about Library Marketing and Outreach}

Outreach has to be more than simply showing and telling. We have to cast aside the librarian-knows-best mentality ... and instead treat our users as partners in the educational process. Our goal should be focused on the objective of student success. ${ }^{13}$

I10 When trying to change how they are perceived, it is critical for libraries to focus on becoming "user-sensitive organizations." 14 Reaching users in a way that demonstrates that library services are valuable to them requires libraries to make users their "partners in the educational process" instead of merely "spectators." 15 Users cannot truly be partners unless libraries understand who they are and what they need. An important first step is to begin to distinguish between the different kinds of library users. It is important to make these distinctions-among students, professors, alumni, and so forth-because we cannot market to all of our users, even all of our student users, in the same ways. ${ }^{16}$

I11 Librarians frequently rely on anecdotal evidence, surveys, suggestion boxes, feedback forms, and focus groups when trying to determine users' needs. While valuable, these methods do not create relationships with users or make the library personal. Instead of making assumptions about what users need, librarians must engage in real conversations with users and collaborate with them to solve problems. By fully engaging in this process, librarians are more likely to get a better sense of the nuances of a user's situation and to identify gaps in users' knowledge. ${ }^{17}$

I12 Another important step in becoming a user-sensitive library is to focus less on library processes and more on creating a library that helps users succeed. ${ }^{18}$ It is important to remember that users are experiencing a constant barrage of information and are "less inclined to investigate something on the off-chance that it's useful." 19 As information experts, librarians can contribute to users' success by showing them that we can help them do their work better-which "might mean quicker, more efficiently, more comprehensively, more cheaply," or something else. ${ }^{20}$ In short, librarians must show users where value lies.

I13 In this way, marketing and outreach are natural extensions of what we already do as librarians; it is our job to figure out what "better" means for our users, and to explain to them exactly how the library can help them achieve better results. In order to accomplish this we must market services, not collections; benefits, not

13. Brian Mathews, Marketing Today's ACademic Library 8 (2009).

14. Id. at 2 .

15. Id. at 8 .

16. Id. at 12-13.

17. See id. at 2.

18. See id. at 8.

19. POTTER, supra note 1 , at 2 .

20. Id. 
features; and results, not processes. We must also market ourselves as the experts who help users find the right information. ${ }^{21}$

\section{Marketing and Outreach Solutions}

I14 Now that we have identified why law libraries need to market to their users and the challenges inherent in such a process, we will describe best practices for marketing and outreach. Though on the surface marketing and outreach may seem to be the same thing, they are quite different. The primary difference is in the purpose or intent behind each method.

q15 The goal of outreach is to connect with users in a meaningful manner that encourages future interactions with the library. Outreach is generally done with a specific cause in mind, such as meeting instructional goals within the legal academy. Outreach efforts typically elicit personal responses from people. An example of an outreach effort would be to create personal or embedded librarian programs to meet individual students' needs.

I16 Marketing is promoting library resources and services more generally. Marketing can be more difficult, because it is critical to create the right message for each user group. It is highly unlikely that a single message will be effective for all types of users. If a group of people is already interested in your library and its services, it is more effective to focus your marketing efforts toward that group on specific services or benefits that will keep them coming back. But how do you get your marketing message across to those who are not yet interested in your library? Marketing strategies and messages must be unique and present something to that uninterested group that they would benefit from individually or be motivated to share with others.

917 While strategies used in outreach and marketing often overlap, the goal or purpose behind the methods are often completely different. To determine the best methods to meet your specific goals, your library should develop a marketing and outreach plan. This plan is a blueprint of a library's marketing objectives and strategies for its brand, services, and resources. The plan helps to identify the targeted audience(s), assess and identify effective strategies to be implemented by all library staff, develop metrics for evaluating the success of marketing campaigns, and save time and money for targeted projects. Having a strong marketing and outreach plan can make the difference between success and failure in marketing and outreach initiatives.

\section{Define Your Marketing and Outreach Objectives}

\$18 Your library mission statement should be the foundation of your marketing and outreach objectives because it describes who you are, why your library exists, your library's primary functions and activities, who your stakeholders are, and what your library does to address the needs of its users. Reviewing and refining your mission statement will help you determine what you want your library to be known for.

21. Id. at $2-3$. 
Your marketing and outreach objectives operationalize your mission. Sample marketing and outreach objectives might include increasing the number of patron visits to the library, the reference desk, or the circulation desk; encouraging repeat visitors to the library; promoting resources or services; and developing or improving your web site. When identifying objectives, make sure they are "SMART."22

- Specific: Your objectives need to be specific. Each objective should address the five Ws (What, Why, Who, Where, and Which): What do you want to accomplish with the project? Why are you setting this objective and why does it benefit the library? Who is going to be involved? Where is it going to take place? Which constraints might you face in trying to achieve this objective?

- Measurable: Your objective needs to be measurable. That is, it should specify how much, how many, how often, and so forth, so that you will know whether the objective has been accomplished. In the era of library justification, it is extremely important to be able to show growth in concrete terms.

- Attainable: How will you accomplish the objective, and will you be able to accomplish it? Your objectives must be realistic and attainable. You want to set your library up for success. You do not want your objectives to be impossible or extreme. To reach your objectives, you may need to develop new attitudes, abilities, and skills. Determine whether the needed skills are available in-house, can be acquired through professional development, or require outside help.

- Relevant: Objectives must be relevant-they must matter. Objectives that are relevant to your boss, your library as a whole, and your law school take priority. Ask these questions in evaluating the relevance of your goals: Does this objective seem worthwhile given the full scope of the project? Is this the right time? Does it match our strategic plan or goals of the larger organization?

- Time-bound: Finally, you need to make sure that your objectives are contained within a specific time period. A strong commitment to a deadline will help a team maintain focus and ultimately facilitate completion. Your objectives should answer the following questions: What can we do today? What can we do six months from now?

Below we have detailed how to achieve SMART goals as you think about creating a marketing and outreach plan in your library.

\section{Gather Research and Background Information}

I19 As you are creating SMART goals, start by listing and evaluating your current marketing strategies. Are your new goals attainable using your current strategies? What are the pros and cons of the strategies your library has in place? Decide

22. For more information on SMART goals, see Locke's Goal Setting Theory: Understanding SMART Goal Setting, MINDTOoLs, http://www.mindtools.com/pages/article/newHTE_87.htm (last visited Aug. 5, 2013); Writing SMART Goals, Univ. of Va. Human Resources, http://www.hr.virginia .edu/uploads/documents/media/Writing_SMART_Goals.pdf (last visited Aug. 5, 2013). 
whether your current marketing tactics are furthering your objectives, and do not be afraid to discontinue practices that have been successful in the past but have outlived their usefulness. Identify your target audience and describe its demographics. Make use of surveys, focus groups, and even circulation records to gather descriptors. Engage in real conversations with your users. Also, determine whether you can tweak your current goals to make them better and SMARTer rather than starting from scratch.

\section{Brainstorm New Marketing Tactics}

\20 Set aside your list of current strategies and have a brainstorming session to come up with new marketing tactics. Here are some ideas to get you started:

- Collect and use personal anecdotes from your patrons.

- Offer virtual library tours to reach new target audiences, such as users who are not local or do not use the physical library.

- Link instructional programs to law school events.

- Provide welcome kits for incoming students so they immediately experience the friendly nature of the library.

- Create a YouTube video or channel that is used solely to educate people about and promote library services.

\section{Establish a Time Line and Budget; Assign Responsibility}

I21 As you are setting SMART goals, make sure to set a completion date and assign a staff member to be responsible for each marketing strategy that you adopt. Create an itemized budget for marketing items such as giveaways, printing, and design.

\section{Create a Marketing Checklist}

I22 It is helpful to create a checklist of tasks that should be completed for every new marketing initiative. Following a checklist ensures that new programs or resources are promoted in a consistent manner, via every available avenue. Sample tasks might include designating a person to e-mail a broad target audience about special events; clearly identifying who will post events to all social media forums and when they will do so; establishing a task force for creating and posting new library signage; or committing to adding all library events to an openly accessible library or law school calendar.

\section{Develop Measures for Success}

I23 As you are creating new objectives, make sure that you establish metrics to evaluate whether your tactics are working. Here are some sample objectives with measurements built in: Improve awareness of the library's web site by increasing traffic by five percent in six months. Gather and analyze survey feedback on instructional sessions from the students or faculty who attended (either virtually or on paper). Compare database usage statistics at six-month intervals as you use web and in-person strategies to promote your databases.

I24 After reviewing your library mission statement and creating marketing and outreach objectives that are Specific (S), Measurable (M), Attainable (A), 
Relevant (R), and Time-bound ( $T$ ), you are ready to develop specific strategies to achieve these objectives. To do that, consider the example marketing and outreach strategies that we have compiled below.

\section{Ideas for Successful Outreach}

\$25 Over the course of the development of our profession, librarians have discovered many ways to reach out to the community. Some use new technologies such as social media. Another possibility is integrating librarians into the legal academy within classrooms and within the law school culture. Over time, the profession has evolved to establish librarians as networkers and collaborators of information, and the strategies that have been found to be most successful capitalize on those expert skills. Examples of outreach ideas can be found in the ALL-SIS Marketing and Outreach Toolkit (allsistoolkit.wordpress.com).

\section{Social Media}

I26 Because almost everyone uses at least one form of social media, it is a logical way to promote library services to patrons. However, libraries should not just post announcements to Facebook and Twitter regarding programs or new resources. Social media sites are meant to be forums for communication, so they are used most effectively when more than one person is taking part in the conversation. Libraries should strive to use social media as a tool to engage their patrons. For example, in addition to posing trivia questions for prizes or soliciting suggestions from students, libraries should also listen to what is being said about the library and the law school. Free programs such as HootSuite (hootsuite.com) or Buffer (bufferapp.com) allow you to create alerts for when a name or phrase is mentioned in a post. An added benefit of a service like HootSuite or Buffer is that you can schedule posts in advance and post to multiple social media sites at the same time. A library presence on LinkedIn may also be a good idea, since it is a more professional site. Many career services departments use it as a means of connecting alumni with potential employers and building the department's professional relationships. Social media accounts are easy to set up, and staff can be responsible for adding new content periodically.

T27 A library might also consider engaging in more directed forms of social media. Library educational and promotional videos can be uploaded to a library YouTube channel. Library photos can be hosted on Flickr. All of these can then be linked to the library's Facebook page, so that you only have to post in one location, and your content is automatically published to all your accounts. Promote a giveaway from your social media sites to gauge use. For example, post a message about a free prize at the reference desk. If no one claims it, then no one saw it, and you need to reevaluate your marketing techniques.

\section{Hosting Celebrations, Open Houses, or Receptions}

\$28 Libraries often have large physical spaces. If that is the case in your library, consider hosting an event in your space that highlights the collection. Or offer to let other departments use the space: this will not cost the library anything other than the time it takes to help set up or clean up. In addition to being a place of 
learning and providing educational services, a library can also serve as a social hub for a school. Libraries seek to create spaces that are conducive to learning and that foster creativity and collaboration. Organizing social activities such as orientation festivals, coffee happy hours, ice cream socials, snacks during finals, movie screenings, yoga classes, and even stress-relief "puppy hours" are all ways that libraries can help promote a more humane and healthy law school experience.

\section{Embedded Librarians}

प29 Embedded librarians are a new hot topic of discussion within the profession. Think about your outreach goals; perhaps they should include starting a new program in which your librarians are a vital part of the clinical experience at your law school. Embedding a librarian into a classroom or clinical experience entails making in-class presentations on research issues, incorporating research assignments that correspond with curricular and clinical structures, and providing oneon-one research consultations for students. ${ }^{23}$ Within this model, librarians can supplement the instructional experience in multiple mediums and formats, such as group presentations, group work, and individualized attention.

\section{Personal Librarians}

\30 Providing individualized service to students and faculty is a specialized and targeted way to increase the visibility of your library. The idea of personal librarians moves away from traditional reference desk interaction and invites the patrons into one-on-one conversations with information experts. Under such a program, all incoming students are assigned a librarian with whom they will hopefully develop a professional relationship. Librarians make the initial contact with the students as they begin their law school careers, as well as at strategic points in their academic experience. Implementing a personal librarian program can have huge positive effects on the reputation of your library within the law school community. ${ }^{24}$

\section{Classroom Sessions and Targeted Training Sessions}

I31 Giving a guest lecture in a substantive law course is a very useful way to inform students of the research resources that are available to them. Students will be more receptive to learning about resources if the research instruction is relevant to what they are studying in class. It is even more beneficial if you can tie your instruction to a specific course assignment. Do not assume that if professors want you to speak to their classes, they will ask. Effective outreach involves being proactive and informing faculty about what you can offer.

I32 You may want to start by targeting professors teaching seminar or paper courses, because the kind of scholarly research and writing required in those classes is not typically covered in a traditional first-year research and writing program.

23. See Brittany Kolonay \& Gail Mathapo, Experimenting with Embedding: A Law School Library Embeds Librarians in Clinics and Seminars, AALL SPECTRUM, June 2012, at 18 (describing experiences with embedding librarians in courses at the University of the District of Columbia). See also Karen Westwood, Deals and Dispute Resolution: Teaching Research Skills in a Short-Term Simulation Class, AALL SPECTRUM, July 2012, at 12.

24. For more on personal librarians, see John B. Nann, Personal Librarians-The Answer to Increasing Patron Contact May Be Simpler than We Think, AALL SPECTRUM, June 2010, at 20. 
Offering these instructional sessions is a key opportunity to teach students tricks and techniques for doing their own research, and it also allows students and faculty to get to know the librarians. People will be more likely to seek help from the library in the future if they have already developed a relationship with the library staff.

\33 In addition to reaching out to faculty to offer research instruction lectures in a for-credit class, librarians can reach out to specific populations of students to provide research training. Groups of students for whom specialized training sessions may be appropriate include faculty research assistants, candidates for law reviews and journals, students working in a clinic, and persons competing in a moot court or trial advocacy competition.

\34 Some academic libraries currently offer research certificate programs to supplement the instruction provided in legal research courses or in guest lectures in substantive law courses. These certificate programs can be short classes or exercises for which participants are awarded a certificate of completion. The library should also consider partnering with other departments in the law school to provide informal instruction sessions. For example, the library can work with career services to show students what resources are available to help them in their job search and interview preparation. Or the library can work with the Information Technology department to demonstrate new technologies or software that students can use in their classes or in law practice.

\section{Ideas for Successful Marketing}

I35 Marketing in libraries has changed drastically as new technologies have flooded the information-management community. Good marketing strategies include both web-based and in-person approaches. Using a combination of these methods may help you reach your marketing goals for the library. Examples of marketing ideas can be found in the ALL-SIS Marketing and Outreach Toolkit (allsistoolkit.wordpress.com).

\section{Blogs}

\$36 Blogs are ubiquitous these days. A great many of them languish without readership, but if blog editors spend the time and energy necessary to make a blog really good, it can be an effective marketing tool. Before starting a blog, the first step you should take is to determine what you hope to accomplish with it. Will it be a source for posting library news and information, or will the content be more in-depth? Once this decision is made, the next step is to make sure that the library staff really does have time and energy to devote to the blog. Make a plan with staff that includes commitments for updating the blog and standards for entries.

\$37 Jordan Steele and Ed Greenlee have written about the process of planning the Biddle Blog at the University of Pennsylvania Biddle Law Library. ${ }^{25}$ The staff there "decided that all of the posts on the Biddleblog would provide substantive and thoughtful commentary and would not merely link to external information 
sources." ${ }^{26}$ After deciding on a focus, they developed a list of topics the library staff could use when writing blog posts. The list included book reviews, reviews of online resources, highlights of special collections within the library, a behind-thescenes look at the library, special exhibits or events, news items related to the law school community, and legal research tips. ${ }^{27}$ To facilitate regular posting, the editors of the blog created a schedule for the librarians, with the goal of posting a new entry every one to two weeks during the academic year. ${ }^{28}$

I38 After those commitments have been made by library staff, the next step is to choose the blogging platform that best suits the library. It is entirely possible that the larger entity of which the library is a part, particularly in academia, will already have a platform that it favors; it may even host its own platform. If that is the case, staff can get training and learn the ropes from in-house IT staff. If not, there are many choices of platform. A few of the major blog-hosting services are WordPress, Blogger, BlogSpot, and TypePad. Some platforms offer more customization options, making it easier to match the blog to the library web site. Other blogging platforms will be easier to get started on without too much fine-tuning, if you want to hit the ground running.

\39 It is also important to consider which widgets to feature on the blog. Widgets are applications, or parts of a web site, that enable a user to perform a specific task, such as looking at the archives of a blog or reviewing a Twitter feed from a newspaper web site. You can use widgets to insert a banner with local news or to scroll job postings along the bottom of the blog. Different blogging platforms will provide different widgets, and it is a good idea to review the widgets that each platform provides before deciding where to host your blog. Take a look at other institutional blogs as well as personal favorites to see what kinds of widgets are most used and most useful. Some examples of law library blogs are available in the ALLSIS Marketing and Outreach Toolkit. A more complete list of law library blogs is available on the CS-SIS wiki. ${ }^{29}$

\section{Annual Reports}

I40 An annual report is a comprehensive report on a library's activities of the preceding year. Annual reports are intended to share information with interested parties about the library's accomplishments. Library annual reports are similar to those of public companies, which provide information to stakeholders. Many libraries already have internal annual reports, but they may not cover the library's marketing efforts. Adding statistics about library marketing events, giveaways, and patron responses can help libraries keep on top of marketing by figuring out which events or promotional products are popular and which are less successful.

If41 Additionally, annual reports themselves can be an excellent way to communicate with library users. Users might be interested in the library budget or

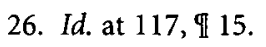

27. $I d$. at $117, \mathbb{1 1} 19$.

28. Id. at $117-18$, श 20.

29. Law Library Blogs, AALL COMPUTING SERVICES SIS, http://aallcssis.pbworks.com/w/page /1189465/Law\%20Library\%20Blogs (last updated July 23, 2013). 
statistics, and an annual report would be a good place to have a recap of important library events. Including photos is a good idea, particularly of events in which patrons took part, so people can look for themselves. Annual reports are also an excellent way to recognize staff achievements, or even just to introduce staff members to library users.

\section{Newsletters}

II42 Newsletters can have some of the same effects that a good annual report does. They keep patrons up to date on library events and programs, are a good way to make contact directly with library patrons, offer reminders about library services, and let people know when events of interest are happening. There has been a trend away from library users actually wanting to speak with librarians and library staff. Offering personalizing information such as short biographies and photos in newsletters can make librarians seem more approachable. There are also less serious options, such as including biographies and photos of the pets of library staff, favorite movies or books, or baby photos. Newsletters can also be a good venue for writing about library participation in student, attorney, or local groups and events.

\$43 Many newsletters have been moving online recently, and there is an argument for replacing them with a library blog. But something that comes directly to the user on a recurring basis, either electronically or in hard copy, can be valuable because it serves as a reminder to those who might not otherwise remember to check a blog.

\$44 It is a good idea to have a standard template for a newsletter. This can be a heading and layout for a print newsletter, or a style sheet for an e-mail newsletter. There are many resources for librarians who wish to design a personalized style sheet, but chances are that some basic HTML coding skills will be required. Remember that a newsletter should be designed to display properly in different formats, and it is possible that the library will need a second style sheet for newsletters to be displayed on smart phones or tablets.

\section{Displays and Exhibits}

T45 Libraries are often commended for their displays. In addition to being educational, displays are an excellent way to promote library resources and programs. Library users can be shown interesting and unusual library books, or reminded of library services. Displays can be used to promote a special collection of the library or to advertise a new database or newly arrived books. Displays can also be an opportunity to work collaboratively with other groups. The library can create a display of recent faculty publications, host an exhibit of photos of a recent student organization event or trip, or put together a showcase of materials relevant to the subject matter of a famous or important case. Offering to create a display promoting a program sponsored by a department or student organization can be an initial outreach effort that may lead to more meaningful interactions in the future.

I46 Think about incorporating QR codes into your displays to direct users to your research guides. Since they are multidimensional, QR codes can contain a lot 
of information, including addresses, text, and telephone numbers. ${ }^{30}$ As people use cell phones more frequently to access web sites, they appreciate not having to type in a web site address. Additionally, with a $Q R$ code, users do not need to search for (or write down or remember) the web site address for what they are viewing, because scanning the code takes them directly to the web site. ${ }^{31}$

\$47 When creating a display, do not just throw together a bunch of books on a theme. Creating displays and exhibits is just like designing a store window or "merchandising." After a display is finished, observe the response to it and make notes. Remember that location can be critical. Think about where you get good foot traffic and what the display may be near. Repurpose book jackets and, most important, apply principles of design such as balance and simplicity. Readability is important. Draw a plan or layout for your display in advance. Grab attention by adding lighting, objects, or color if possible.

\section{Flyers, Banners, Posters, Signs, Brochures, and Pamphlets}

I48 Brochures and pamphlets are an excellent way to introduce the library and some of its most important services to users, and as such can be a simple way to get started in your marketing. While they may seem to have been overshadowed by digital marketing options these days, it is important not to underestimate the usefulness of a good brochure. They add color and appeal to a library desk, are relatively simple to make, and are easy to travel with and give out. Potential library users may forget what they read about online or have heard of by word of mouth, but they can be reminded by a physical item like a brochure. If you are lucky, a member of your library staff might already have some expertise in designing brochures, but there are also plenty of free or low-cost alternatives available online for designing a personalized pamphlet, including several templates from Microsoft. Remember that brochures and pamphlets should not be too text-heavy.

\section{Promotional Prizes and Giveaways}

I49 Giveaways are always popular. Anyone is happy to have a free pen, and if the pen reminds them of your library it is a win-win situation. When selecting promotional giveaways, choose functional items that fill a need or serve a purpose. It is hard to go wrong with the standard giveaway options-pens, pencils, Post-it notes, water bottles, and so forth. Other things to consider include highlighters, coffee mugs, earplugs, coasters, USB drives, mouse pads, and screen cleaners (all of these items are often cheaper in bulk). Edible items are another favorite: chocolates adorned with the library logo are a sure-fire hit. Putting a high-quality print of the library logo onto a standard label makes it easy to decorate chocolate wrappers, and your bonbons can look surprisingly professional. The best kind of giveaway is something unique that will get patrons talking.

I50 In addition to smaller giveaway items that library users can simply take, it is also a good idea to have larger items that can be won or earned (e.g., gift cards or

30. Darla W. Jackson, Standard Bar Codes Beware-Smartphone Users May Prefer QR Codes, 103 LAW LiBr. J. 153, 154, 2011 LAW LiBR. J. 9, II 5.

31. Id. at 155, II 9 . 
study guides). For example, students could receive prizes for answering reference questions, finding a hidden clue in the stacks, or tracking down a specific resource. Such a competition could be advertised on the law library blog, Twitter feed, Facebook page, or in the newsletter. The cost of giveaways may be hard to justify with tight library budgets, so consider soliciting coupons or vouchers from local businesses to use as prizes.

\section{Word of Mouth and Reputation}

151 One of the strongest marketing strategies available is your library's reputation as it is spread by word of mouth. ${ }^{32}$ Word of mouth marketing, at its core, means that your services are giving people a reason to talk about you and recommend your products and services. Word of mouth and reputation are built on strong relationships with your users and with your internal team. Develop a strong team message that you want to guide your audience in spreading. You may have a mission statement that you can prominently display in your library; alternatively, you could create a customer service statement to be posted throughout your library. Talk up your library to your constituencies and tell them about your success stories. Try adding a "wall of fame" in your library where users can post their own stories of successful encounters with library staff. The key is to make the conversation easy so that the positives of your library flow from one mouth to another without interruption.

\section{Conclusion}

I52 The ALL-SIS Task Force on Library Marketing and Outreach and this white paper were created because of a call from academic law librarians for a comprehensive discussion of marketing and outreach. We hope that we have contributed meaningfully to this discussion while providing all types of law librarians with ideas and strategies to use in marketing their libraries. Our primary goals were to identify the challenges that academic law libraries currently face, to dive deep into the literature and anecdotal conversations to find out why libraries need to develop marketing and outreach plans, and to compile and offer examples of marketing and outreach successes to allow other librarians to learn from one another. We have attempted to blend a theoretical approach to marketing and outreach with practical examples provided in the toolkit. Though this white paper is in no way comprehensive, we believe that it provides a solid foundation for a dynamic conversation that begins now and adapts with our profession. Readers should be sure to look at the toolkit on our web site (allsistoolkit.wordpress.com) for specific examples to help them in their own libraries.

32. See Cindy Spohr, Let's Give Them Something to Talk About-Word of Mouth Is an Important Campaign to Add to Your Marketing Mix, AALL SPECTrum, May 2008, at 10. 